\title{
The Correlation Between Metacognitive Awareness Level and Self-Directed Learning Readiness of Undergraduate Nursingand Midwifery Students
}

\author{
Mukaddes Örs ${ }^{1}$, Osman Titrek ${ }^{2}$ \\ ${ }^{1}$ Dr. Lecturer, Üniversity of Akdeniz, Faculty of Health Sciences, Department of Health Management, Turkey \\ ${ }^{2}$ Prof.Dr.,Üniversity of Sakarya, Faculty of Education Sciences, Department of Educational Sciences, Turkey \\ Correspondence: Mukaddes Örs, Dr. Lecturer, Üniversity of Akdeniz, Faculty of Health Sciences, Department of Health \\ Management, Turkey.
}

Received: October 2, 2018

Accepted: November 22, $2018 \quad$ Online Published: November 29, 2018

doi:10.11114/jets.v6i11a.3819

URL: https://doi.org/10.11114/jets.v6i11a.3819

\begin{abstract}
The aim of this study was to investigate the relationship between Self-directed Learning readiness and Metacognitionof undergraduate students nurses and midwifery. The research is conducted in a public university in the city center of Amasya with 398 undergraduate nursing and midwifery students in 2017-2018 academic years. A descriptive correlational design was used. A structured questionnaire consisted of two parts: Part I: Socio-demographic data, Part II: Fisher's Self-Directed Learning Readiness scale and Part III: Metacognitive Awareness Inventory (Schraw \& Dennison, 1994).Descriptive statistics of the students' demographic attributes were presented. In order to determine whether there was a correlation between the students' self directed learning readiness and their Metacognitive Awareness perceived, the Pearson Moment Correlation coefficient was was calculated.The results showed that (1). There is a positive moderate but significantly relationship between metacognitive awareness and Self-directed Learning Readiness scores. (2). There is a significant relationship between metacognitive awareness and Self-directed Learning Readiness subscores.Metacognition awareness is a predictor of SDLR.
\end{abstract}

Keywords: self directed learning readiness, metacognitive awareness, continuing professional development, lifelong learning, nurse and midwife, undergraduate students

\section{Introduction}

What is expected from the human model required by the information society is adapting to life by updating his/her knowledge and becoming a qualified individual. When individuals limit their learning process only with the education they are given at school, it becomes more difficult for them to keep up with the rate of the increase of information in our age. Thus, it is of importance for individuals to acquire self-directed learning skills in terms of creating learning opportunities and ensuring their self-development.

In its broadest sense, self-directed learning is defined as the management of an individual's own learning process by himself/herself. Although there are various descriptionsof self-directed learning in the literature (Knowles 1975; Iwasiw, 1987; Spencer and Jordan, 1999; Slevin and Lavery, 1991; Fisher, King and Tague 2001), there is no general and commonly accepted definition.

In spite of the fact that the definitions of self-directed learning differ, there are a number of common discourses used in the definitions. Among these are the individuals' assuming the responsibility of their own learning, planning about their learning, carrying out the actual learning and carrying out the evaluation of the learning (Caffarella, 2000; Merriam and Caffarella, 1999).

The experts of the field of self-directed learning have developed a number of self-directed learning models based on different viewpoints (Candy, 1991; Brockett and Hiemstra, 1991; Garrison, 1997). According to these models, the individuals learning on a self-directed basis need to have the required thinking skills and to have developed certain affective structures. In this context, individuals' gaining self-directed learning skills depends on the precondition of having the cognitive, affective and psychomotor behaviors, i.e. their readiness. Self -directed learning readiness is defined as the degree the individual possesses the attitudes, talents and personality features necessary for self-directed learning (Wiley, 1983, p. 182). 
There are some structures that are considered to be important for the individuals to learn on a self-directed basis and for their readiness. First of these, the self-direction, is related to the individuals' using and benefiting from the learning sources for the achievement of their learning targets (Garrison, 1997). Candy (1991) cites the desire for learn and the capacity to manage the learning process in relation to the concept of self-direction. The individuals need to make the learning continuous and meaningful by selecting and accessing the correct materials, by providing feedbacks and by asking questions. The self-direction of individuals is considered to be of importance for them to obtain positive results from their initiatives for learning as well. The second structure is the self-control of the learners, which means them taking under control and organizing the internal situations (effort, ability, motivation) and the external situations (luck, opportunity, risk, etc.) that have the potential to affect the learning process, which is deemed to be important in terms of the success of the process (Miller, Fitch and Marshall, 2003). The last structure considered to be important in terms of regulating the learning environments in order to mobilize themselves and achieve their objectives is the willingness of the individuals for self-directed learning (Wang and Dennett, 2014).

It has been found out that individuals need to have some critical cognitive, affective and psychomotor features in order to ensure their readiness for self-directed learning. A number of factors including the characteristic features of individuals, their attitudes towards learning, their cognitive and affective competency, the level of their education, their personality traits, their learning style, their life satisfaction, their health status, their self-direction, their critical thinking and awareness, their motivation, their general self-efficacy and their academic achievements play an important role in acquiring the skill of self-directed learning (Corno, 1992; Mezirow, 1985, Fisher et al., 2001). And one of these features is the metacognitive thinking (Hanor and Hayden, 2004). Brown (1987) defined the metacognitive thinking as the awareness about and regulation of the thinking processes used by students in preplanned learning and problem solving situations. Metacognition, the capacity to recognize and regulate his or her own thinking in real time, was identified as one of three components fundamental to the teaching and learning process (Young, 2010). Ample research has shown that metacognitive awareness is essential to student learning (Artzt\&Armour-Thomas, 1992; Garner \& Alexander, 1989; Perfect \& Schwartz, 2002; Pressley \&Ghatala, 1990; Robson, 2006; Swanson, 1990; Naseri at al., 2017 ).Metacognition is a fundamentalskill in critical thinking and self-regulated, lifelong learning because the learners are use to monitor and regulate reasoning, comprehension, and problem-solving (Melissa et al., 2017).

The metacognitive structure has been stated to be composed of two main components, which are the cognitive knowledge and the cognitive regulation. Cognitive knowledge denotes what individuals know about their own cognition or about cognition as a general concept. On the other hand, cognitive regulation is related to the process of controlling the cognitive activities and whether the cognitive objectives have been achieved or not (Hangrove, 2007). When the metacognitive thinking and its sub-dimensional properties are taken into consideration, it appears to be an important structure in terms of self-directed learning. According to Van Merriënboer\&Sluijsmans (2009), usage of the metacognitive strategies such as planning, monitoring and evaluation is a skill needed in the process of self-directed learning. When these situations are taken into consideration, the ability of individuals to think in a metacognitive way and to develop effective strategies can be said to affect their readiness for self-directed learning.

Acquiring the self-directed learning skills is a matter of process for the students of midwifery and nursing. Thus, ensuring the readiness of the students of midwifery and nursing for self-directed learning and the improvementof their metacognitive thinking strategies depends on their educational background. Having self-directed learning skills is a factor in increasing the professional competence and performance of the students of midwifery and nursing who will serve in the future (Rowe, 2004). Moreover, having metacognitive awareness is of importance for them in terms of better managing their own cognitive structure. As Davis and Davis (2001) also stated, learning is ancontinuous progression and it is intensively self-directed. Thus, the students need to select, monitor and evaluate the subject, the depth and the way of learning they need by themselves (Doğanay and Demir, 2011). It has been found out that many students give the priority to "being unable to understand" when they list the problems they while they are learning throughout their academic study. Starting from this point of view, it can be said that the most prominent part of a good education is teaching the students how to learn, how to remember and how to control and direct their own learning in an effective way (Çakıroğlu, 2007). Thus, the students of midwifery and nursing need to graduate having acquired the metacognitive awareness throughout their process of education and having ensured their readiness for self-directed learning. Doğanay and Demir (2011) pointed at the importance of imparting the metacognitive awareness strategies to students. In addition, they emphasized that gaining the skills of planning, managing, monitoring and evaluating their own learning processes would contribute to them being more independent learners.

The application of Self directed learning skills offers a way to enable students to 'help themselves' and to adapt to requirements and changes. One of general principles for fostering SDL skills is to provide for both subject-matter knowledge and self-directed learning skills together (Francom, 2010, 32). Metacognition is intrinsically part of Self directed learning and refers to the conscious planning, control and evaluation of his/her own cognitive processes 
(Sternberg \& Sternberg, 2012, 234).

Many studies testing the correlation between the readiness for self-directed learning and the metacognitive awareness and investigating their effects on each other have been found in the literature (Kincanon, Gleber and Kim, 1999; Long, 2000; Hanor and Hayden,2004; Shannon and College, 2008; Havenga et al., 2013; Karataş, 2017). However, no study investigating the correlation between the readiness for self-directed learning and the metacognitive awareness that have been conducted on midwifery and nursing students in Turkey has been found in the literature. The present study is considered to be important in terms of contributing to filling this gap. It is considered to be important that the midwifery and nursing students, as the midwives and nurses of the future, should possess the self-directed learning and metacognitive awareness skills in order to be able to better manage their own learning processes. The university education process appears to be important in ensuring the self-directed learning among the undergraduate students of midwifery and nursing, and in developing their metacognitive awareness. Depending on this, it is an object of curiosity whether the metacognitive awareness of the undergraduate students of midwifery and nursing and their readiness for self-directed learning are ensured or not. In this context, it was considered necessary to conduct the present study by addressing the variables of the readiness for self-directed learning in students of midwifery and nursing, and their metacognitive awareness.

In line with the information given above, it seems important to test the correlation between the level of readiness for self-directed learning in students of midwifery and nursing and their level of metacognitive awareness, which is an important structure in terms of that readiness. Based on this importance, the findings and results of the study are expected to create awareness on being able to see the effect of the midwife and nurse training programs on the level of development of these skills. In this regard, it is aimed that the study will contribute both to the midwife and nurse training programs and to the related literature.

Investigation whether there is a correlation between stdents' readiness for selfdirected learning and their metacognitive awareness in the light of this information constitutes the problem of the present study.

\section{Objective}

The aim of the present study is to determine thecorrelation between students's level of readiness for self-directed learning and their metacognitive awareness. within this scope, answers were sought for the following questions:

1) Is there a statistically significant correlation between students' readiness for self-directed learning and their metacognitive awareness?

2) Is there a statistically significant correlation between the levels of Cognitive Knowledge and Cognitive Regulation with nursing and midwifery student' Self-Direction?

3) Is there a statistically significant correlation between the levels of Cognitive Knowledge and Cognitive Regulation with nursing and midwifery student' desire for learning?

4)Is there a statistically significant correlation between the levels of Cognitive Knowledge and Cognitive Regulation with nursing and midwifery student' Self-Control?

\section{Method}

\section{Method of the research}

This is a quantitative study.The relational screening model, which is a general screening model, was used in the present study. "Relational screening models are research models that aim to determine the existence and/or degree of the covariance between two or more variables (Karasar, 2014).

\section{Population -Sampling}

The target population of the study comprised a total of 398 students studying, in the academic year of 2017-2018, in the Departments of Midwifery $(n=103)$ and Nursing $(n=295)$ in the Faculty of Health Sciences. In the present study, it has been aimed to reach to the entire target population without using any sample selection method. Due to the reasons such as being on leave or sick leave throughout the dates when the study was conducted, 385 students (97 of which were midwifery students and 288 nursing students) could be reached. A total of 385 completed questionnaires were returned (response rate $=89 \%$ ) and analyzed. Before starting the study, a written permission was obtained from the Office of the Chancellor of the University, and volunteerism was taken as the basis in the participation of the students in the study. The students in the target population were informed about the purpose of the study, and they were asked to fill in the data collection tools based on the principle of volunteerism. The applications were carried out by the researcher in person between the dates of February 19, 2018, and April 17, 2018. The students accepting to take part in the study were informed that the information taken from them would be evaluated only by the person who applied the questionnaire and it wouldn't be examined by anyone else. 


\section{Data Collection Tool}

The questionnaire included demographic data (age, academic level, department, monthly Income, leisure activities). we used two tool in this study: the SDLR scale andMetacognitive Awareness Inventory (MAI).

Self-Directed Learner Readiness Scale (SDLR)

In order to determine the self-directed learning readiness levels of the students, the Self-Directed Learning Readiness Scale (SDLRS) that was developed by Fisher et al. (2001) and adapted to Turkish by Şahin and Erden (2009) was used. The original form of the scale was developed by Fisher, King and Tague (2001) by collecting data from the instructors taking charge in the nursing undergraduate education in the University of Sydney.

This tool comprise of a 40-item questionnaire using a five-point Likert scale (1-5) of strongly disagree, disagree, undecided, agree and strongly agree. Overall scores range 40-200; higher scores reflect stronger Self- Directed Learning Readiness Scale/ SDLRS. Mean scores >150 indicate a high level of Self- Directed Learning Readiness Scale, while mean scores $\leq 150$ represent a low level of Self- Directed Learning Readiness Scale (Fisher at al., 2001). The SelfDirected Learning Readiness Scale identified three subscales: Self-management, desire for learning and self-control. The self-management subscale was descript by 13 items and, it reflected these characteristics of being able to manage one's own learning. Maximum score obtainable from this subscale scale was 65. Similarly, desire for learning subscale was defined by 12 items with these items relating to the desire for learning. Maximum scores obtainable from this subscale were 60. Self control subscale was defined by 15 items which related to the features self-control or being in control of one's own learning. Maximum scores obtainable from this subscale were 75.

Adaptation of the Self-Directed Learning Readiness Scale developed by Fisher et al. (2001) to Turkish was carried out by Şahin and Erden (2009) on 130 classroom teachers. The results of the explanatory factor analysis which was carried out showed that the first factor explained $15.7 \%$ of the total variance belonging to the scale, the second factor explained $13.9 \%$ and the third one $13.5 \%$. Since the factors of the original scale developed by Fisher et al. (2001) had been named by taking the content of the items into account, the same factor names were used in the present study as well. The first factor was named "self-direction", the second one "desire for learning" and the third one "self-control". The three factors explain $42.5 \%$ of the total variance. The Cronbach's Alpha coefficient calculated for the internal consistency and reliability of the scale changed between 0.83 and 0.85 . Fisher et al. (2001) conducted the consistency and reliability study of the scale in Sydney on 201 nursing students studying at the undergraduate level. Fisher et al. (2001) found the Cronbach's Alpha coefficient to be 0.857 for the sub-dimension of "self-direction", 0.843 for the sub-dimension of "desire for learning" and 0.830 for the sub-dimension of "self-control". The Cronbach's Alpha coefficient was calculated for each sub-dimension in order to test the reliability of the measurements in the present study, which was found to be 0.881 for the sub-dimension of "Self-management", 0.889 for the sub-dimension of "desire for learning" and 0.908 for the sub-dimension of "self-control". The Cronbach's Alpha coefficient of this study 0.953. Nunally (1978) emphasizes that the coefficient for the reliability measurement needs to be over 0.70. Tezbaşaran (1997, 47) states that a reliability coefficient that can be considered to be adequate for a Likert-type scale should be as close to 1 as possible. Based on the reliability coefficients obtained, the scale can be said to be a reliable measurement tool.

\section{MetacognitiveAwareness Inventory (MAI)}

The metacognitive awareness inventory is a self-assessment tool to identify level of metacognition in adults and developed by Schraw and Sperling-Dennison (Schraw \& Dennison, 1994) and adapted to Turkish by Akın, Abacı and Çetin (2007) was used. It is a 52 item and 5 likert type inventory (1-5). The five levels of awareness are "Always True" (5), "Sometimes True" (4), "Neutral" (3), "Sometimes False" (2), and "Always False" (1). Scores are ranging between 52 and 260. The MAI consists of two main components and eight sub-components of metacognition. Each one of the 52 questions aligns with one of the eight sub-components. One main component is Knowledge of Cognition and includes the following sub-components: Declarative Knowledge (7 item), Procedural Knowledge (4 item), and Conditional Knowledge (6 item). The other main component, Regulation of Cognition, includes the following components: Planning (7 item), information management (9 item), Monitoring (8 item), Debugging (5 item), and Evaluating (6 item).

Metacognitive AwarenessInventory was adopted into Turkish by Akın, Abacı and Çetin (2007) with a study done on university students. According to this, during reliability test of the scale, reliability coefficient acquired by test-retest was found 0.95; the reliability coefficient obtained by split-half method was 0.91; Cronbach's alpha coefficients were 0.95 (Akin at al., 2007). The Cronbach's Alpha coefficient was calculated for each sub-dimension in order to test the reliability of the measurements in the present study, which was found to be 0.891 for the sub-dimension of "Declarative Knowledge " 0.796 for the sub-dimension of "Procedural Knowledge" 0.797 for the sub-dimension of "Conditional Knowledge", 0.882 for the sub-dimension of "planning”, 0.888 for the sub-dimension of "monitoring", 0.839 for the sub-dimension of "evaluating", 0.851 for the sub-dimension of "Debugging", and 0.881 for the sub-dimension of “information management". The Cronbach's Alpha coefficient of this study 0.923 . 


\section{Analysis techniques}

The SPSS-22.0 package software was utilized to analyze the collected data. The demographic characteristics of the participating students were analyzed in terms of frequency and percentage. Kolmogorov-Smirnov and Shapiro-Wilk Tests were conducted on the data in order to determine whether they were normally distributed. Since the groups were not normally distributed ( $\mathrm{p}<.05)$, the Pearson Moment Correlation coefficient was considered (Büyüköztürk, 2010; Kalayc1, 2010). Correlation was used in the investigation of the correlation between the sub-dimensions of the readiness for self-directed learning, which constituted the dependent variables of the study, and the sub-dimensions of the metacognitive awareness, which constituted the independent variables of the study (Büyüköztürk, 2010, 155-166; Sönmez and Alacapınar, 2016, 198-214).

\section{Findings}

When Table 1 is examined, it can be seen that $81.30 \%$ of the students participating in the study were female and $18.70 \%$ were male, $29.09 \%$ were attending the $2^{\text {nd }}$ grade-level, $26.23 \%$ the $4^{\text {th }}$ grade-level, $23.12 \%$ the $1^{\text {st }}$ grade-level and $21.56 \%$ the $3^{\text {rd }}$ grade-level, $74.81 \%$ were studying in the department of nursing and $25.19 \%$ in the department of midwifery, It can be seen that the average monthly income of $42.08 \%$ of the students is over $1.000 \mathrm{TL}$. In terms of leisure activities, $32.472 \%$ preferred reading, $45.97 \%$ preferred watching TV. $5.45 \%$ preferred going to the movie-theatre, and $15.062 \%$ preferred sport (Table 1).

Table 1. Descriptive characteristics of the participating students.

\begin{tabular}{|c|c|c|}
\hline Variables & $\mathbf{n}$ & $\%$ \\
\hline \multicolumn{3}{|l|}{ Gender } \\
\hline Female & 313 & 81.30 \\
\hline Male & 72 & 18.70 \\
\hline Total & 385 & 100.00 \\
\hline \multicolumn{3}{|l|}{ Academic Level } \\
\hline $1^{\text {st }}$ Grade & 89 & 23.12 \\
\hline $2^{\text {nd }}$ Grade & 112 & 29.09 \\
\hline $3^{\text {rd }}$ Grade & 83 & 21.56 \\
\hline $4^{\text {th }}$ Grade & 101 & 26.23 \\
\hline Total & 385 & 100.00 \\
\hline \multicolumn{3}{|l|}{ Department } \\
\hline Nursing & 288 & 74.81 \\
\hline Midwifery & 97 & 25.19 \\
\hline Total & 385 & 100.00 \\
\hline \multicolumn{3}{|l|}{ Monthly Income } \\
\hline $500 \leq$ Turkish Liras & 119 & 30.91 \\
\hline 500-1000 Turkish Liras & 104 & 27.01 \\
\hline 1000> Turkish Liras & 162 & 42.08 \\
\hline Total & 385 & 100.00 \\
\hline \multicolumn{3}{|l|}{ Leisure Activities } \\
\hline Reading & 125 & 32.47 \\
\hline Watching Television & 177 & 45.97 \\
\hline Movie and Theatre & 21 & 5.45 \\
\hline Sports Activities & 58 & 15.06 \\
\hline None & 4 & 1.04 \\
\hline Total & 385 & 100.00 \\
\hline
\end{tabular}

The 'Pearson Moment Correlation' coefficient (r) was examined in order to determine the magnitude and significance level of the correlation between the two scales employed within the scope of the present study. The results of the analysis conducted in order to determine the correlation between them are presented in the Table 2.

We calculated the relationship between total SDLR scale scores and total metacognitive awareness inventory scores. All SDLR scales were positive moderate but significantly correlated with total metacognitive awareness inventory scores: $r$ (385) $.486, \mathrm{p}=.000$. 
Table 2. Correlation between self- directed learning readiness total scores and metacognition aweraness inventory for undergraduate nursing and midwifery students total scores $(\mathrm{n}=385)$.

\begin{tabular}{lccc}
\hline & & $\begin{array}{c}\text { Self-directed-learning } \\
\text { readiness }\end{array}$ & $\begin{array}{c}\text { Metacognition } \\
\text { aweraness }\end{array}$ \\
\hline $\begin{array}{l}\text { Self-directed-learning } \\
\text { readiness }\end{array}$ & $\mathrm{r}$ & 1 & $.486^{* *}$ \\
Metacognition & $\mathrm{p}$ & & .000 \\
aweraness & $\mathrm{r}$ & $.486^{* *}$ & 1 \\
& $\mathrm{p}$ & .000 & \\
\hline
\end{tabular}

$* *$ Correlation is significant at the 0.05 level.

'Pearson Moment Correlation' coefficient ( $r$ ) was examined in order to determine the correlation between the sub-factors of the two scales used in the present study. The results of the analysis conducted in order to determine the correlation between them are presented in the Table 3 .

we explored the relationships between SDLR subscales and Metacognitive Awareness inventory subscales. The self-management subscale had a positive moderately significant correlation with Cognitive Knowledge: $r(385)=.407, p$ $=.000$; Cognitive Regulation: $\mathrm{r}(385)=.424, \mathrm{p}=.000$. In other words, depending on the increase in the self-management scores, the cognitive knowledge scores and cognitive regulation scores also were found to increase. The desire for learning subscale had a positive moderate significant correlation with cognitive knowledge: $\mathrm{r}(385)=.353, \mathrm{p}=.000$; cognitive regulation: $\mathrm{r}(385)=.382, \mathrm{p}=.000$. The Self-Control Skills subscale had moderate significantly correlation with Cognitive Knowledge: $\mathrm{r}(385)=0.382, \mathrm{p}=.000$; Cognitive Regulation: $\mathrm{r}(385)=.344, \mathrm{p}=.000$. The results are presented in Table 3.

Table 3. Correlation between self- directed learning readiness subscale scores and metacognition aweraness inventory for undergraduate nursing and midwifery students subscale scores $(n=385)$

\begin{tabular}{|c|c|c|c|c|c|c|}
\hline Variables & & Self-management & $\begin{array}{l}\text { Desire for } \\
\text { learning }\end{array}$ & Self-control & $\begin{array}{l}\text { Knowledgeof } \\
\text { cognition }\end{array}$ & $\begin{array}{c}\text { Regulation of } \\
\text { cognition }\end{array}$ \\
\hline \multirow[t]{2}{*}{ Self-management } & $\mathrm{r}$ & 1 & & & & \\
\hline & $\mathrm{p}$ & & & & & \\
\hline \multirow{2}{*}{$\begin{array}{l}\text { Desire } \\
\text { learning }\end{array}$} & $\mathrm{r}$ & $.559^{* *}$ & 1 & & & \\
\hline & $\mathrm{p}$ & .000 & & & & \\
\hline \multirow[t]{2}{*}{ Self-control } & $\mathrm{r}$ & $.474^{* * *}$ & $.565^{* *}$ & 1 & & \\
\hline & $\mathrm{p}$ & .000 & .000 & & & \\
\hline \multirow{2}{*}{$\begin{array}{l}\text { Knowledge } \\
\text { cognition }\end{array}$} & $\mathrm{r}$ & $.407^{* *}$ & $.353^{* *}$ & $.382^{* *}$ & 1 & \\
\hline & $\mathrm{p}$ & .000 & .000 & .000 & & \\
\hline \multirow{2}{*}{$\begin{array}{l}\text { Regulation } \\
\text { cognition }\end{array}$} & $\mathrm{r}$ & $.424^{* *}$ & $.382^{* *}$ & $.344^{* *}$ & $.774^{* *}$ & 1 \\
\hline & $\mathrm{p}$ & .000 & .000 & .000 & .000 & \\
\hline
\end{tabular}

$* *$ Correlation is significant at the 0.05 level.

\section{Results, Conclusions and Recommendations}

Our results showed that metacognitive awareness scores were a positive moderate significant correlation to overall SDLR scale scores. Depending on the increase in the scores of the students of midwifery and nursing in the scale of readiness for self-directed learning, their metacognitive awareness scores also were found to increase. According to the findings concerning the first sub-purpose of the study, the metacognitive awareness of the students of midwifery and nursing is a factor affecting the readiness for self-directed learning.

The two metacognitive awareness dimensions, cognitive knowledge and cognitive regulation, were moderately but significantly related with the self management subscale scores. According to the findings concerning the second sub-purpose of the study, the cognitive knowledge and cognitive regulation of students of midwifery and nursing, i.e. their metacognitive awareness, are factors affecting the self-direction. The individuals are expected to regulate their 
cognition by carrying out the evaluation of what they know and what they don't in an effective way from the beginning to the end of the process. Being able to do this, being active in the learning process and assuming the responsibility of learning depend on the self-management level of the individuals. In addition, the individuals can have access to the correct information and ensure their self-control in the use of cognitive strategies by selecting the correct sources owing to their self-management (Candy, 1991). In this context, having knowledge about their own cognition and being able to select their own cognitive strategies using this knowledge are of importance for individuals in their self-directed learning process. Organizing these cognitions and strategies, in turn, depends on the level of self-direction, because the self-direction can be likened to the conductor of the metacognitive thinking (Garrison, 1997). However, since individuals' being aware of themselves and the ways of learning is a situation connected with the metacognitive awareness (Doğanay, 1997), metacognition is essential for self-direction. The learners with metacognitive awareness can gain awareness about their own thoughts, and they can learn by means of struggling when they encounter obstacles (Hoyt and Sorensen, 2001; Peverly, Brobst and Morris, 2002). Self-management has the quality to trigger the metacognitive thinking in terms that it includes the students' becoming aware of and monitoring themselves and the process (Çakıroğlu, 2007), and thus it is an important structure in terms of encouraging the self-directed learning.

The two metacognitive awareness dimensions; cognitive knowledge and cognitive regulation, were a positive moderately but significantly correlated with the self-control subscale scores. With self-control and self-management, students can also engage in SDL well enough to acquire basic nursing knowledge, skills, and behaviors. According to the findings concerning the third sub-purpose of the study, the cognitive knowledge and cognitive regulation of the students of midwifery and nursing are factors affecting their self-control in the process of self-directed learning. The students of midwifery and nursing are expected to establish a balance between the internal and external variables by means of the power of the self-control. The desired acts of learning can be realized as a result of the effective and correct use of this power, and this requires the students of midwifery and nursing to be able to think in a metacognitive way. Doğanay (1997) suggests that the development of the metacognitive awareness skills brings about the self-control skills. Learners' taking the variables in question under control is related, to a great extent, to their awareness about these features of themselves. This awareness is very important for the learners to take initiative and assume the responsibility about their own learning, to direct their learning and to learn on a self-management way (Baltacı and Akpınar, 2011), because the individuals who cannot ensure their self-control will be faced with the possibility of being controlled by the variables in question and failing in their initiative to learn. The individuals who have the control over the learning use the learning sources in an effective way, and this, in turn, affects the development of learning strategies in a positive way. In this context, it can be said that the metacognitive awareness of individuals is effective in the control of the learning activities and tasks in the process of self-directed learning.

The two metacognitive awareness dimensions; cognitive knowledge and cognitive regulation, were a positive moderate significantly correlated with the desire for learning. Desire for learning, which is used to determine the motivation of students for learning and whether they are able to reflect on this motivation, is the foundation of SDL. Only students with a desire for learning can engage in learning using the available resources, and monitor and regulate the strategies they use to asist themselves in conscious learning. it appears that our findings do support this view. According to the findings concerning the fourth sub-purpose of the study, the cognitive knowledge and cognitive regulation of the students of midwifery and nursing are factors affecting their desire for learning in the process of self-directed learning. In the process of self-directed learning, the motivation of the students of midwifery and nursing and their desire for learning are expected to be at the desired level. In this sense, metacognitive awareness not only contributes to the cognitive processes and regulations of individuals, but also ensures that the learners become willing for learning and develop self-confidence, which are considered to be important for the self-directed learning (Peirce, 2003). According to the findings obtained in the study conducted by Clardy (2000) in five institutions on 56 people, there are three important factors affecting the self-directed learning, and one of these is the desire of the learners for learning. If the desire of learners for learning is below the required level, then their learning slows down and their willingness decreases when they encounter an unexpected situation, have a feeling of failure in the process of learning or get mentally tired during the learning process (Shannon and College, 2008). If students are able to think in a metacognitive way, then they can perform the planning, control, monitoring and evaluation in a correct way, and thus the probability of experiencing negative feelings decreases. The metacognitive awareness level of students is considered to be important in the realization of the mentioned expectations and in fulfillment of the requirements. When people have different knowledge on and skills of metacognitive awareness, the levels and speeds of their learning also differ. The action research carried out by Shannon \& College (2008) revealed that when the students' awareness level concerning their thinking and learning processes increased, the level of their self-directed learning skills also increased.

In brief, the relevant literature and findings show that metacognitive awareness is one of the structures necessary for the students of midwifery and nursing to learn on a self-directed way. The studies in the relevant literature support the 
findings of the present study. Long (2000), Hanor and Hayden (2004), Shannon and College (2008), Havenga et al. (2013), Kincanon, Gleber and Kim (1999) have emphasized the metacognitive awareness as an important variable ensuring the readiness for self-directed learning. In addition, the processes of self-directed learning and metacognitive awareness are two main structures that are related to and support each other. It was seen when the definitions of self-directed learning are examined in the relevant literature that individuals assuming the responsibility of their own learning, carrying out the planning for their learning, realizing the learning situation and conducting the evaluation are the common components used in these definitions (Merriam and Caffarella, 1999). On the other hand, Pintrich and Groot (1990) suggest that metacognitive awareness comprises the strategies of individuals for planning, supervising/controlling and qualifying their own cognition. Accordingly, metacognitive thinking is a natural component of the process in planning for the self-directed learning, in ensuring the control of cognitive processes, and in carrying out the evaluation (Havenga et al., 2013). Miller and Geraci (2011) state that metacognitive thinking is important for the individuals to be able to make cognitive regulations in the management of the learning process. From these statements, having metacognitive awareness at an adequate level appears to be important for the students of midwifery and nursing to achieve self-directed learning. In addition, it can be said that the level of the self-directed thinking skills is effective in managing the process of self-directed learning in a successful way. In the study they conducted on university students, Kincanon, Gleber and Kim (1999) obtained the finding that teaching metacognitive thinking strategies to university students contributed to the development of their self-directed learning skills. Likewise, it was found out in the study conducted by Havenga et al. (2013) that improvement of metacognitive thinking level in computer teachers contributed positively to the development of their self-directed learning skills as well.

Consequently, there are a number of cognitive and affective features the students of midwifery and nursing should possess in order to ensure their readiness for self-directed learning. These features are important structures in terms of the successful management and accomplishment of the self-directed learning process as well. One of these structures is metacognitive awareness. It is considered that the students with metacognitive awareness will be at an advantageous position in terms of ensuring their readiness for self-directed learning. Moreover, the readiness of the students for self-directed learning can be predicted by looking at the level of their metacognitive awareness. Accordingly, it can be said that the readiness of the students of midwifery and nursing for self-directed learning will also increase when their metacognitive awareness is increased.

The suggestions based on the findings and results of the present study are as follows: In order to ensure the improvement of the self-direction levels of students, extramural supports and learning opportunities facilitating the learning can be developed. Within this framework, the students of the faculties of health sciences can be presented with a rich environment in terms of ensuring the provision of sources. The lecturers can be recommended to set up the course process in a way that will increase the metacognitive awareness of the students and ensure their readiness for self-directed learning. In addition, "self-directed learning" can be included in the midwifery and nursing training programs as an independent course or as a part of the content of a course in order for the students to be able to acquire the self-directed learning skills. As for the recommendations for researchers, qualitative studies that will reveal what factors can be effective in increasing the self-direction levels of the students of midwifery and nursing, their self-control and their willingness for learning can be conducted. Studies can be carried out by forming experimental settings intended for monitoring the level of the changes taking place in the self-direction, self-control and willingness for learning of the students. In the context of the results of the present study, other cognitive and affective structures related to self-directed learning can be investigated. Qualitative studies that will investigate the perception and belief levels of the students of midwifery and nursing concerning self-directed learning and their own metacognitive awareness can be carried out. Longitudinal studies investigating the levels of readiness of the midwife and nurse training programs for self-directed learning and the levels of their effectiveness on metacognitive awareness can be conducted.

\section{References}

Akin, A. (2006). Relations between achievement goal orientations and cognitive awareness, parent attitudes and academic achievement Unpublihsed master thesis. Sakarya: University of Sakarya, Social Sciences Institute.

Artzt, A. F., \& Armour-Thomas, E. (1992). Development of a cognitive - metacognitive framework for protocol analysis of mathematical problem solving in small groups. Cognition and Instruction, 9(2), 137-175. https://doi.org/10.1207/s1532690xci0902_3

Balaban, D. A., \& Bayındır, D. (2016). The Investigation of the relationship between the level of metacognitive awareness, self-directed learning readiness and academic Achievement of preschool teacher candidates. Universal Journal of Educational Research, 4(11), 2533-2540. https://doi.org/10.13189/ujer.2016.041106

Baltaci, M., \& Akpinar, B. (2011). The effect of web based instruction on the metacognition awareness levels of learners. Mustafa Kemal University Journal of Social Sciences Institute, 8(16), 319-333. 
Brockett, R. G., \& Hiemstra, R. (1991). Self-direction in adult learning: Perspectives on theory, research, and practice. New York: Routledge.

Brown, A. L. (1987). Metacognition, executive control, self-regulation, and other more mysterious mechanisms. In F. E., Weinert, \& R. H., Kluwe (Ed.), Metacognition, motivation and understanding (pp. 65-116). Hillsdale, NJ: Lawrence Erlbaum.

Büyüköztürk, Ş., Çakmak, E., Akgün, Ö. E., Karadeniz, Ş., \& Demirel, F. (2010). Scientific research methods. Fifth edition Edit. Ankara: Pegem Academy.

Caffarella, R. S. (2000). Goals of self-learning. G. A. Straka (Ed.), Conceptions of self-directed learning: Theoretical and conceptual considerations. (pp. 37-48). Munster, Germany: Waxmann.

Çakıroğlu, A. (2007). Metacognition. Journal of Turkey Social Research. 11(2), 21-27.

Candy, P. C. (1991). Self-direction for lifelong learning: A comprehensive guide to theory and practice. San Francisco: Jossey-Bass Publishers.

Clardy, A. (2000). Learning on their own: Vocationally oriented self-directed learning projects. Human Resource Development Quarterly, 11(2), 105-125. https://doi.org/10.1002/1532-1096(200022)11:2<105::AID-HRDQ2>3.0.CO;2-5

Corno, L. (1992). Encouraging Students to take responsibility for learning and performance. Elementary School Journal. 93(1), 69-83. https://doi.org/10.1086/461713

Davis, R., \& Davis, A. B. (2001). Managing your own learning. (Translation Baykara, A.). Ankara: Kapital Medya Hizmetleri A.Ş.

Doğanay, A. (1997). Use of strategies related to cognitive awareness during course listening. Çukurova University Faculty of Educational Journal, 2(15), 34-42.

Doğanay, A., \& Demir, Ö. (2011). Comparison of the level of using metacognitive strategies during study between high achieving and low achieving prospective teachers. Educational Sciences: Theory \& Practic 11(4), 2011-2043.

Fisher, M., King, J., \& Tague, G. (2001). Development of a self-directed learning readiness scale for nursing education. Nurse Education Today, 21, 516-525. https://doi.org/10.1054/nedt.2001.0589

Francom, G. M. (2010). Teach me how to learn: Principles for fostering students' self-directed learning skills. International Journal of Self-Directed Learning, 7(1),29-44.

Garner, R., \& Alexander, P. (1989). Metacognition: Answered and unanswered questions. Educational Psychologist, 24, 143-15. https://doi.org/10.1207/s15326985ep2402_2

Garrison, D. R. (1997). Self-directed learning: toward a comprehensive model. Adult Education Quarterly, 48(1), 18-33. https://doi.org/10.1177/074171369704800103

Hangrove, R. A. (2007). Creating creativity in the design studio: Assessing the impact of metacognitive skill development on creative abilities. A doctoral dissertation North Carolina University, University of North Carolina Press, USA.

Hanor, J., \& Hayden, K. (2004). Advancing growth in educational technology using reflective practice and self-directed learning. International Journal of Self-Directed Learning, 1(2), 53-62.

Havenga, M., Breed, B., Mentz, E., Govender, D., Govender, I., Dignum, F., \& Dignum, V. (2013). Metacognitive and problem-solving skills to promote self-directed learning in computer programming: Teachers' experiences. $S A$ e-DUC Journal, 10(2), 1-14.

Hoyt, J. E., \& Sorensen, C. T. (2001). High school preparation, placement testing, and college remediation. Journal of Developmental Education, 25, 26-33.

Iwasiw, C. (1987).The role of the teacher in self directed learning. Nurse Education Today, 7, 222-227. https://doi.org/10.1016/0260-6917(87)90005-0

Kalayc1, S. (2010). SPSS applied, multivariate statistical techniques. (Fifth edit) Asil Publishing, Ankara-Turkey.

Karasar, N. (2014). Scientific research method. (26. Edit). Ankara: Nobel Publishing.

Karataş, K. (2017). Predicting teacher candidates' self-directed learning in readiness levels for terms of metacognitive awareness levels. H. U. Journal of Education, 32(2), 451-465. https://doi.org/10.16986/HUJE.2016017218 
Kennedy, G., Petrovic, T., Judd, T., Lawrence, J., Dodds, A., Delbridge, L., \& Harris, P. (2000). The personal learning planner: A software support tool for self directed learning. Australasian Society for Computers in Learning in Tertiary Education (ASCILITE).

Kincannon, J., Gleber, C., \& Kim, J. (1999). The effects of metacognitive training on performance and use of metacognitive skills in self-directed learning situations. Paper presented at the 21st National Convention of the Association for Educational Communications and Technology (AECT), February 10-14, Houston, Texas.

Knowles, M. (1975). Self-directed learning: A guide for learners and teachers. New York: Associated Press.

Long, H. B. (2000).Understanding self-direction in learning. In: LONG, H.B., \& Associates (eds), Practice and theory in self-directed learning. Schaumburg, IL: Motorola University Press: 11-24.

Melissa, S. Medina., A., Castleberry. N. \& Adam, M. P. (2017). Strategies for Improving Learner metacognition in health professional education, American Journal of Pharmaceutical Education, 81(4), 1-14

Merriam, S. B., \& Caffarella, R. S. (1999). Learning in adulthood (2.Ed.). San Francisco: Jossey-Bass. http://books.google.com.tr/books/about/Learning_in_Adulthood.html?id=ffaKVcPVC84C\&redir_esc=y.

Mezirow, J. (1985). A critical theory of self-directed learning. In S. Brookfield (Ed.), Self-directed learning: From theory to practice. New directions for continuing education, No. 25. San Francisco: Jossey-Bass, pp. 17-30. https://doi.org/10.1002/ace.36719852504

Miller, C. A., Fitch, T., \& Marshall, J. L. (2003). Locus of control and at-risk youth: A comparison of regular education high school students and students in alternative schools. Education, 123(3), 548552.

Miller, T. M., \& Geraci, L. (2011). Training metacognition in the classroom: the influence of incentives and feedback on exam predictions. Metacognition Learning, 6, 303-314. https://doi.org/10.1007/s11409-011-9083-7

Naseri, M., Kazemi, M. S., \& Motlag, M. E. (2017). The Effectiveness of metacognitive skills training on increasing academic achievement. Iranian journal of educational sociology, 1(3), 83-88.

Nunnally, J. C. (1978). Psychometric theory (2nd ed). New York: McG-raw-Hill.

Peirce, W. (2003). Metacognition: Study strategies, monitoring, and motivation http://academic.pg.cc.md.us/ wpeirce/MCCCTR/metacognition.htm.

Perfect, T. J., \& Schwartz, B. L. (2002). Toward an applied metacognition. In T. J. Perfect, \& B. L. Schwartz (Eds.) Applied metacognition. New York: Cambridge University Press. https://doi.org/10.1017/CBO9780511489976

Peverly, S. T., Brobst, K., \& Morris, K. S. (2002). The contribution of reading comprehension ability andmetacognitive control to the development of studying in adolescence. Journal of Research in Reading, 25, 203-216. https://doi.org/10.1111/1467-9817.00169

Pintrich, R. R., \& DeGroot, E. V. (1990). Motivational and self-regulated learning components of classroom academic performance, Journal of Educational Psychology, 82, 33-40. https://doi.org/10.1037/0022-0663.82.1.33

Pressley, M., \& Ghatala, E. S. (1990). Self-regulated learning: Monitoring learning from text. Educational Psychologist, 25(1), 19-33. https://doi.org/10.1207/s15326985ep2501_3

Robson, J. (2006). Teacher professionalism in further and higher education: Challenges to culture and practice. London: Routledge.

Rowe, W. (2004). A case study of the influence of teacher efficacy and readiness for self-directed learning on the implementation of a growth-oriented teacher performance appraisal process in one school district, Unpublished doctoral dissertation., University of Ottawa, Canada.

Şahin, E., \& Erden, M. (2009). Reliabılity and valıdıty of self-dırected learnıng readıness scale (SDLRS. E-Journal of New World Sciences Academy, 4(3), 695-706.

Schraw, G., \& Sperling-Dennison, R. (1994). Assessing metacognitive awareness. Contemporary Educational Psychology, 19, 460-470. https://doi.org/10.1006/ceps.1994.1033

Shannon, S. V., \& College, W. S. (2008). Using metacognitive strategies and learning styles to create self-directed learners. Institute for Learning Styles Journal, 1, 14-28.

Slevin, D., \& Lavery, M. (1991). Self-directed learning and student supervision. Nurse Education Today, 11, 368-377. https://doi.org/10.1016/0260-6917(91)90037-B

Sönmez, V., \& Alacapınar, F. G. (2016). Sampled scientific research methods. Fourth edit. Anı Publishing, Ankara-Turkey, 2016, pp.198-214, ISBN 978-605-5213-92-3. https://doi.org/10.1136/bmj.318.7193.1280 
Spencer, J. A., \& Jordan, R. K. (1999). Learner centred approaches in medical education. British Medical Journal, 318 , 1280-3.

Sternberg, R. J., \& Sternberg, K. (2012). Cognition. 6th ed. Australia: Wadsworth, Cengage Learning.

Swanson, H. L. (1990). Influence of metacognitive knowledge and aptitude on problem solving. Journal of Educational Psychology, 82(2), 306-314. https://doi.org/10.1037/0022-0663.82.2.306

Tezbaşaran, A. (1997). Likert Type Scale Development Guide. Second edit. Turkish Psychological Association Publication, Ankara-Turkey.

Van Merriënboer, J. J. G., \& Sluijsmans, D. M. A. (2009). Toward a synthesis of cognitive load theory, four-component instructional design, and self-directed learning. Educational Psychology Review, 21(1), 55-66. https://doi.org/10.1007/s10648-008-9092-5

Wang, V. C. X., \& Dennett, S. K. (2014 ). Pedagogy vs andragogy Organizations In Wang, Victor C. X (Ed.), Handbook of research on education and technology in a changing society. Hershey, PA: IGI Global, pp.318-330. https://doi.org/10.4018/978-1-4666-6046-5

Wiley, K. (1983). Effects of a self-directed learning project and preference for structure on self-directed learning readiness. Nursing Research, 32(3), 181-185. https://doi.org/10.1097/00006199-198305000-00011

Young, A. E. (2010). Explorations of metacognition among academically talented middle and high school mathematics students (Order No. 3413529). Available from ProQuest Dissertations \& Theses Full Text. (749394961). Retrieved from http://search.proquest.com/docview/749394961 ?accountid=12725

\section{Copyrights}

Copyright for this article is retained by the author(s), with first publication rights granted to the journal.

This is an open-access article distributed under the terms and conditions of the Creative Commons Attribution license which permits unrestricted use, distribution, and reproduction in any medium, provided the original work is properly cited. 